\title{
Factors Affecting Prolonged Working Life for the Older Workforce: the Swedish Case
}

\section{Tomas Berglund}

Professor, University of Gothenburg, Department of Sociology and Work Science, Sweden

I Daniel Seldén'

Senior lecturer and researcher, University of Gothenburg, Department of Sociology and Work Science, Sweden

\section{Björn Halleröd}

Professor, University of Gothenburg, Department of Sociology and Work Science, Sweden

\begin{abstract}
The aim of this paper is to uncover some of the mechanisms that could make the older workforce willing and able to stay employed. Our focus is on work-related factors that predict the probability of staying in employment despite entitlement to old-age pension. The analyses are based on data from the first and second waves of the Panel Survey of Ageing and the Elderly (PSAE). The focus is on employed persons aged 52-59 years in 2002/2003 and the probability that they were still employed in 2010/2011. The analysis focuses on the work situation for the respondents in 2002-2003. Our analysis shows that physical job demands (negatively) and job satisfaction (positively) have an effect on the probability of staying. However, a counteracting force seems to be a norm to quit related to aging, emphasized by the institutionalized pension system, and the values and preferences connected to life as a pensioner.
\end{abstract}

\section{KEYWORDS}

Job demands / job satisfaction / prolonged working life / retirement

DOI

10.18291/njwls.v7il.81396

\section{Introduction}

etirement does not lend itself to a simple definition; it is a construct that has many different connotations. In some cases, retirement means almost a ceremonial departure from working life. In other words, it means retiring from a permanent position or a radical down-shifting from work. As a construct, however, the concept of retirement has had a major influence on how the older work force is viewed and how the older work force views their role or the ending of that role within the labor market.

The past 40 years have seen a shift in how policy-makers talk about aging in working life (Hamblin, 2010). In fact, recent policy reforms have meant that there are currently new opportunities for and demands on people to remain in employment after

\footnotetext{
${ }^{1}$ Corresponding author: Daniel Seldén, Department of Sociology and Work Science, Skanstorget 18, Box 720, SE-405 30 Gothenburg, Sweden (E-mail: daniel.selden@socav.gu.se)
} 
retirement age (Euwals et al., 2010). Thus, the key argument is no longer that the old workforce must give way for the young (often presented as the right to withdraw from labor). Instead, old age is discussed as an active and productive phase. This new rhetoric can be seen in light of increasing welfare costs, which are partly due to longer life expectancies. That is why early retirement has also become increasingly problematic, since it leads to a reduction of the labor force, implying a reduced tax base for governments (OECD, 2006; Radl, 2013). The problem is that an increasing number of citizens are dependent on an ever-decreasing workforce at the same time as a longer life expectancy increases the demand for goods and services, which in turn increases the demand for labor. This situation seems to present both challenges and opportunities. A central challenge is that working conditions for the older workforce need to be of sufficient quality for these workers to postpone their retirement decision as long as possible (Tuomi et al., 2001). Consequently, research is needed to understand the mechanisms that affect individuals' choices to either stay in employment or leave for retirement.

The aim of the present paper is to uncover some of the mechanisms that may make the older workforce willing and able to stay employed. Our case country is Sweden and we will concentrate on work-related factors that take into account individuals' resources to meet the demands of the job.

The remainder of the paper begins with a presentation of previous research on retirement behavior. We then discuss our analytical point of departure and present our empirical data. We follow this by presenting our results and, finally, a discussion of our main findings.

\section{Background}

In the present study, we highlight factors that may cause employees to stay in their jobs after reaching the age of eligibility for old-age pension. Most research in this area has concentrated on the retirement process, that is, the factors that cause employees to leave working life for retirement (Schalk et al., 2010; Wang \& Shultz, 2010). The decision to leave the labor market is described in the literature as a major life event, a detachment process that makes employees feel less committed to work. The push model (or ejection model) describes the factors that explain why people leave the labor market. It is a 'negative' model in the sense that it describes the problems that old employees can experience, which eventually support the decision to retire (demands, pressure from the work collective, negative attitudes from the employer, health, ageism, etc.). The pull model (or attraction model), on the other hand, describes the positive and voluntary factors of retirement (more leisure, for example). This model involves a weighting of pros and cons between working and private life before a decision is made ( $\mathrm{Radl}, 2013)$.

\section{Work-related factors}

The main focus of the present study is on the significance of work-related factors. Previous research has found several such factors to be of importance for the retirement process (van den Berg et al., 2008). In general, dissatisfying jobs and jobs with high physical and psychological demands are believed to push employees into retirement, 
while creative and complex jobs seem to retain workers in employment (Elovainio et al., 2005; Gobeski \& Beehr, 2009; Hayward et al., 1989; Kubicek et al., 2010; Lin, 2001; Szubert \& Sobala, 2005; Wang, 2007).

The so-called demand-control model, developed by Karasek and Theorell (Karasek, 1979) and later developed to include social support (Karasek \& Theorell, 1990) (henceforth, the JDCS model), has been very influential in explaining the effects that workrelated factors have on work stress and psychological well-being (Van der Doef \& Maes, 1999). The significance of these factors is less clear-cut when it comes to retirement decisions. First, there is strong evidence that physical job demands push employees into early retirement (Lund et al., 2001; Lund \& Villadsen, 2005), and the same holds for monotonous work (Henkens \& Tazelaar, 1997; Reitzes et al., 1998). However, evidence for the pushing effect of a psychologically strenuous job is less conclusive. For instance, Salonen et al. (2003) found that having a physically but not psychologically strenuous job affects early retirement among food industry workers.

In the JDCS model, job control is central to managing stress and pressure in the work situation. When it comes to explaining retirement behavior, however, the job control factor has been shown to only have minor relevance (Borg, 1999; Lund \& Villadsen, 2005; Mein et al., 2000). Moreover, the evidence for the relevance of social support is ambiguous. Some research has shown that social support reduces the risk of early retirement (Elovainio et al., 2003; Viklas Krause et al., 1997), while other studies have revealed no such relevance (Borg, 1999).

The JDSC model has been criticized for focusing solely on control and social support. Influenced by Siegrist's effort-reward imbalance model (Siegrist, 2008), Bakker and Demerouti (2007) developed the Job Demands-Resource (JD-R) model, which incorporates a more general concept of 'resources' in order to take a more comprehensive view on the factors that may buffer the effect of job demands on strain in the work situation. The main effect of job demands is believed to be the exhaustion of physical and psychological personal resources (Bakker \& Demerouti, 2007). This leads to strain, loss of personal energy, and often health problems. Job resources, on the other hand, are aspects of the job (physical, psychological, social, or organizational in nature) that are functional in achieving work goals, reducing the physiological and psychological costs of job demands, or in stimulating personal growth and learning. In this way, job resources can be used to reduce strain and pressure. Furthermore, job resources are also believed to have a motivational effect independent of job demands and related to organizational outcomes. However, only a few studies have used the JD-R model to study retirement decisions (Demerouti \& Bakker, 2011; Kubicek et al., 2010). Schreurs et al. (2010) noted that job demands and job resources were related to work enjoyment, which is associated with decisions about whether to retire early. Accordingly, they suggested that the motivational process is more important than the health impairment process (Schreurs et al., 2010).

\section{Personal and family factors}

There are also influential microlevel personal factors and family-related factors that affect retirement behaviors. It is important to identify these factors, as they may serve as controls in a study of the significance of the work situation for retirement, or they may 
interact with work-related factors. According to previous studies, several factors appear to be important at the personal level (Hansson et al., 1997; Shultz \& Wang, 2007). One decisive factor is the financial status of the individual (Quinn et al., 1990; Szinovacz \& Davey, 2005). Here, rational choice considerations are central and it is assumed that older workers will choose to retire if they have sufficient financial resources in the absence of paid work to uphold their consumption and living standard. However, not all research has identified a connection between scarce financial resources and motivation to continue working (von Bonsdorff et al., 2009). Another important factor is health, which constrains possibilities to remain in employment (Mutchler et al., 1997; Shultz \& Wang, 2007; Wang, 2007). Factors related to the individuals' family situation also affect retirement decisions (Elovainio et al., 2003). The labor market attachment of the spouse is of particular importance, as are caring responsibilities (Henkens, 1999; Henkens \& Tazelaar, 1997; Henkens \& Van Solinge, 2002; Szinovacz \& DeViney, 2000; Szinovacz et al., 2001). It is worth noting that different gender patterns seem to exist in this regard: men tend to stay in work if the spouse suffers from poor health, while the opposite applies to women (Hansson et al., 1997).

The main factor of importance for the retirement process is of course age. This could be seen as a rather simple explanation for retirement decisions since it presupposes a natural decline of physical and cognitive functions with age. However, the explanations for this relationship between age and retirement are not that straightforward. The 'deficiency hypothesis of aging' suggests that it is only natural for older workers to be pushed out of the labor market through retirement when they are no longer productive enough ( $\mathrm{Radl}, 2013)$. Much of the research suggests that the underlying mechanism is either declining abilities and human capital (Evers \& Ester, 2013) or deteriorating health (Adams \& Rau, 2011; Shultz \& Wang, 2007). However, some researchers argue that age-related decline should not be viewed as a linear or a deterministic process ( $\mathrm{Radl}, 2013$ ). The argument is that such a mechanistic model lacks the insight that work capacities change rather than decline with age. If there is a turning point when a worker's physical and cognitive functions start to decline, there are good reasons to believe that employers should tend to deselect older workers or that older workers' motivation for work also would decline in accordance with their work performance (Nilsson, 2016; Radl, 2013; van der Heijden et al., 2008). Moreover, some have argued that there are no clear-cut differences between younger workers, with promising human assets, and older workers, with deteriorating human assets (Thijssen \& Rocco, 2010).

Of course, there are activities that employers can utilize to counteract employees' declining physical functions. Opportunities to work out during office hours may serve as a means to meet the physical requirements of the job (Rayson, 2000). Such activities could be an important factor in reducing issues such as absence and ill-health retirement (Rayson, 2000).

However, age is obviously also related to the pension system. In 1913, Sweden established its first basic pension system, and a more encompassing and earnings-related income pension system was introduced in 1960. The formal retirement age in both these systems was initially set at 67 , but was lowered to 65 in 1976. In the basic pension system, 65 is still the retirement age, while today's reformed income pension has a flexible pension age. The current Swedish pension system has four main layers. The guarantee pension-as the name indicates_-guarantees a basic pension for people with no or a 
very low accumulated labor market income. The second layer is called income pension and is strictly related to accumulated labor market income. The third layer consists of collective occupational pensions that are negotiated between the unions and the employer federation as a part of the collective barging process, which means that they look different in different sections of the labor market. The fourth layer consists of private pensions and savings. In this reformed system, pensions are based on life-time income and it is estimated that being employed for an extra year increases the annual pension income by $10 \%$ (SOU, 2012). Thus, in contrast to the former system, working longer has a direct impact on the expected income pension because income from work will always increase the expected pension, as will any postponement of payment from the income pension system.

As institutional theory emphasizes, reforms can create new values and expectations that become incorporated into individuals' way of understanding their reality (Svallfors, 2007; van der Heijden et al., 2008). Thus, the introduction of pensions transformed the view of old age, and old age has become a period of life that people could evaluate and look forward to as a time free from the obligation of wage labor. The institutionalization of a given pension is further strengthened by coordination with other policies. As pointed out by a recent public investigation (SOU, 2013), there is a complicated web of legislations and negotiated agreements that are based on the assumption of a set retirement age, and parts of the income protection systems, such as the Employment Protection Act, unemployment insurance, and sickness benefits, are still organized around the idea of a set retirement age. There are also normative age criteria that describe the normal and expected method of retirement, and therefore act as a pressure mechanism that an individual will have to fend off if she or he wants to make a 'deviant' choice (Atchley, 1982; Ekerdt, 2010). One of the reasons why people might want to make the deviant choice to remain in employment is that they strongly associate their identity with the social role they hold. Retirement and the subsequent feeling of no longer being valued and needed may be perceived as a penalty rather than an opportunity to realize new goals in life (Morrison, 1986).

The institutionalized and normative aspects of retirement are reflected by the fact that even though the age of 65 may slowly be losing its dominance as the normative retirement age, it remains the preferred retirement age for most Swedes (Örestig et al., 2013). Therefore, we could expect that leaving work for a life on pension becomes a more prioritized preference the more one closes in on the stipulated retirement age, which means that other aspects directly related to work become less important.

\section{Analytical Considerations}

In the present study, we used the conceptualization of the JD-R model to identify factors in the work situation that may affect older employees' decision to leave employment or remain employed. Especially, we find the analytical distinction between demands and resources at work as very fruitful in the process of finding factors that retain older workers in employment. Following the JD-R model, a main resource for acting and operating in life and work is our biological human organism. However, aging is generally associated with diminishment of this resource, both physiologically and mentally (Adams \& Rau, 2011; Evers \& Ester, 2013; Shultz \& Wang, 2007). Even 
though there are other views on the significance of aging in work (Radl, 2013; Thijssen \& Rocco, 2010), we have preliminarily followed the conventional view on aging as a process of declining biological resources. Therefore, aging may result in an experience of increasing demands, even in a situation of unchanged objective working conditions. This general effect may increase the probability of retirement as the worker gets older and is one of the main reasons why old-age pensions exist. It is also possible that job demands and age interact by multiplying the effect of demands on the risk of retiring with increasing age.

There are a few implications of this general presumed effect of aging. The first is to study whether there are job resources that have a direct effect on reducing the risk of work cessation. In relation to the general JD-R theory, these direct effects are believed to work via motivation and job satisfaction. Therefore, job resources related to job satisfaction are important. Previous research has shown that the nature of the work task (whether it is varied, challenging, etc.), autonomy, feedback and support, the workload, salary, and working time are all central to job satisfaction (Spector, 1997). Of further rele vance is that job satisfaction has been found to be an important antecedent of turnover cognitions and actual turnover (Hom \& Kinicki, 2001; Tett \& Meyer, 1993). Therefore, we expect low job satisfaction to be related to a higher risk for some kind of transition, and in older age, the most probable transition is out of the labor force. In research focused on retirement behavior, Kubicek et al. (2010) found that job satisfaction had a small but significant negative effect on the risk of actual retirement.

However, job resources are also believed to have an indirect buffering effect on job demands. In the present context, this could mean an interaction effect with age on the probability of staying in employment. Some job resources may reduce the 'withering' effect of aging, thereby prolonging labor market participation. There are two main job resources that are likely to have this effect. The first is control/autonomy in the work situation, which enables employees to plan and arrange their working day. This could be more central in enabling older employees to keep up with the work pace. The second-social support, especially instrumental support (help from workmates) may also be vital. For example, workmates can compensate for diminishing physical abilities. However, it is also possible that the work experience of older workers is appreciated by workmates and management, which provides extra motivation to keep working.

The above reasoning presumes that the effect of age on the retirement process is related to diminishing personal resources (health, cognitive abilities, etc.). Some resources found in the work situation can buffer this effect and serve as external resources that enable older workers to continue working. However, the mechanism underlying the presumed age effect may not have so much to do with diminishing personal resources as with the norms and values connected with retirement, that is, either a strong preference to retire or a social pressure to retire is applied when older workers are entitled to pensions (Radl, 2013). An indication of such processes would be that the moderating effects of demands or resources move in the opposite direction to that expected above. If the negative effect of job demands on remaining in work becomes smaller the older one gets, or if the positive effect of job resources weakens with age, this would mean that both job demands and job resources are becoming less and less important for the decision to stay. We will interpret this as a sign of a strengthening of the age norm/preference for retirement.

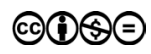




\section{Data and Methods}

The analyses are based on data from the first and second wave of the Panel Survey of Ageing and the Elderly (PSAE). PSAE is an integrated part of the Swedish Survey of Living Conditions (ULF) (Vogel \& Häll, 2006), which has been conducted annually since 1975. What makes PSAE special in relation to ULF is that the sample size is increased in the 65-plus age group, the upper age limit previously used in ULF (age 84) is removed, and the questionnaire is extended. Data were collected in 2002 and $2003(t)$ and in 2010 and $2011(t+8)$. ULF/PSAE has a partial panel design, and more than half of the sample is included in both waves. The general response rate of ULF is approximately $75 \%$.

The focus of the present study is on employed persons who were aged 52-59 years in 2002/2003 and the probability that they were still employed in 2010/2011. The reason for the narrowing to this age category is that they were, in principle, entitled to old-age pensions in 2010/2011. The Swedish pension rules state that one is entitled to old-age pension from the age of 61 and has the right to work; that is, they are covered by the Employment Security Act until age 67 in an open-ended contract. It seems as though this flexibility has had an effect on Swedes' decisions to leave employment. The actual mean pension age increased from about 62.5 years in 2002 (calculated based on the population over 50) to close to 64 in 2010 [Pensionsmyndigheten (Swedish Pensions Agency), 2014].

We also included 60-year-old employees in the analysis as a reference category. This age category can be regarded as a pre-retirement referent, that is, a category just before being subjected by the retirement system. Therefore, we should see a marked difference between this age category and the subsequent one. However, several employees among this group already have the right to retire according to their collectively agreed occupational pension, which may decrease the difference of retirement risk between the referent and the other age categories. The number of respondents included in the analysis (before internal drop-outs) is 764 .

The dependent variable measuring employment/nonemployment at $t+8$ consists of a question asking whether the individual classifies his/her main status in one of three categories (working; working, but not main occupation; not working at all). The two first alternatives have been collapsed, so the dependent variable becomes a dichotomy. However, this means that individuals that de facto are pensioners (receiving pensions) at $\mathrm{t}+8$ but still regard themselves as working-for example, if they have their own company-will be classified as in employment. Table 1 summarizes a cross-tabulation of age and employment. Approximately 55\% are still working 8 years later, but a distinct age pattern is visible, indicating a decreasing probability of being in employment the older a person gets.

The focus of the subsequent analysis was on work-related factors that predict the probability of staying in employment despite entitlement to old-age pension. The analysis focuses on the work situation for the respondents in 2002-2003. We have no

Table I Employment at $\mathrm{t}+8(2010 / \mathrm{I})$ in relation to age category. Percent.

\begin{tabular}{lccccccccc}
\hline Age & 60 & 61 & 62 & 63 & 64 & 65 & 66 & 67 & Total \\
\hline Employed & 87.9 & 81.0 & 68.5 & 77.9 & 62.4 & 51.4 & 31.0 & 28.1 & 55.4 \\
$\mathrm{~N}$ & 66 & 63 & 54 & 86 & 101 & 140 & 126 & 128 & 764 \\
\hline
\end{tabular}


information on what happened between 2002-2003 and 2010-2011. Therefore, the effects of the factors included may be regarded as rather long term, that is, the outcome is shown 8 years later.

Guided by the JD-R model, we focus on working conditions that may function as job demands and job resources. Four variables measure different aspects of possible job demands. Two of them measure physical and psychological demands. The questions relate these demands directly to the individual's work capacity: How do you assess your present work capacity in relation to the physical [psychological] demands of your job? Responses range from 0 (very bad) to 10 (very good). These two indicators are not optimal in terms of operationalizing job demands because they mix the individuals' own work capacity with demands that may origin in the work environment. However, they are the only indicators available in ULF that directly refer to physical and psychological demands. Two other variables that are initially regarded as job demands are the frequency of staying overnight ( 1 'never'-5 'many times a week') and whether one has direct contacts with clients and customers (no/yes). The latter variable is commonly associated with the so-called 'burnout' phenomenon, that is, intense contact with clients/patients can lead to a feeling of being drained of mental energy (Maslach \& Jackson, 1981) unless job resources are satisfactory, then client/patient contacts could be a source of motivation (Tourangeau et al., 2010).

Job resources include variables measuring job discretion and social support. Discretion is measured by a summative index $(\alpha=0.79)$ based on three questions: Do you have the [freedom to decide] how the work should be done?; [...] what to do?; [...] when to do the work? The response alternatives range from 1 'great freedom' to 4 'no freedom' and the scale ranges from 0 to 9 , where 9 indicates greater autonomy. Two questions measure social support from managers and from peers ( 1 'yes, mostly' to 3 'no'; reversed in the analysis). We have also included a variable indicating whether the workplace offered opportunities for sports/training during working time (no/yes).

From a theoretical point of view, job satisfaction is an important variable (Clark, 2005). Many of the working conditions variables are thought to be mediated by satisfaction, which makes employees more motivated and therefore willing to stay in employment. Job satisfaction is measured using the following question: How do you feel on your way to your job? It includes six response alternatives ranging from 'happy and satisfied when thinking about the work waiting' to 'feel strong aversion to the work'.

We have included several controls in order to conduct a stringent test of the focal independent variables regarding the respondent's previous work situation. First, we include variables on the respondent's type of job in 2002/2003 (private/public sector, working time, and contract type). Second, some important background factors are included (gender, civil status, education). All background variables relate to the first measurement point, that is, 2002/2003. Age is of central theoretical concern in the analysis and expected to have a strong negative effect on the probability that the individual was still in employment in 2010/2011. An indicator of the respondent's health is also included and measured by the individual's self-rating on a five-point scale (very goodvery bad). The health indicator refers to $2002 / 2003$. However, we also include an indicator of the change in health (i.e., health 2010/2011 minus health 2002/2003). The coming analyses also control for the respondent's income in 2002/2003 as well as a ratio measuring the respondent's contribution to the total household income (as a percentage). This last variable indicates how dependent the household is on the respondent's income. Table 2 presents some descriptive statistics as well as correlations between the variables. 


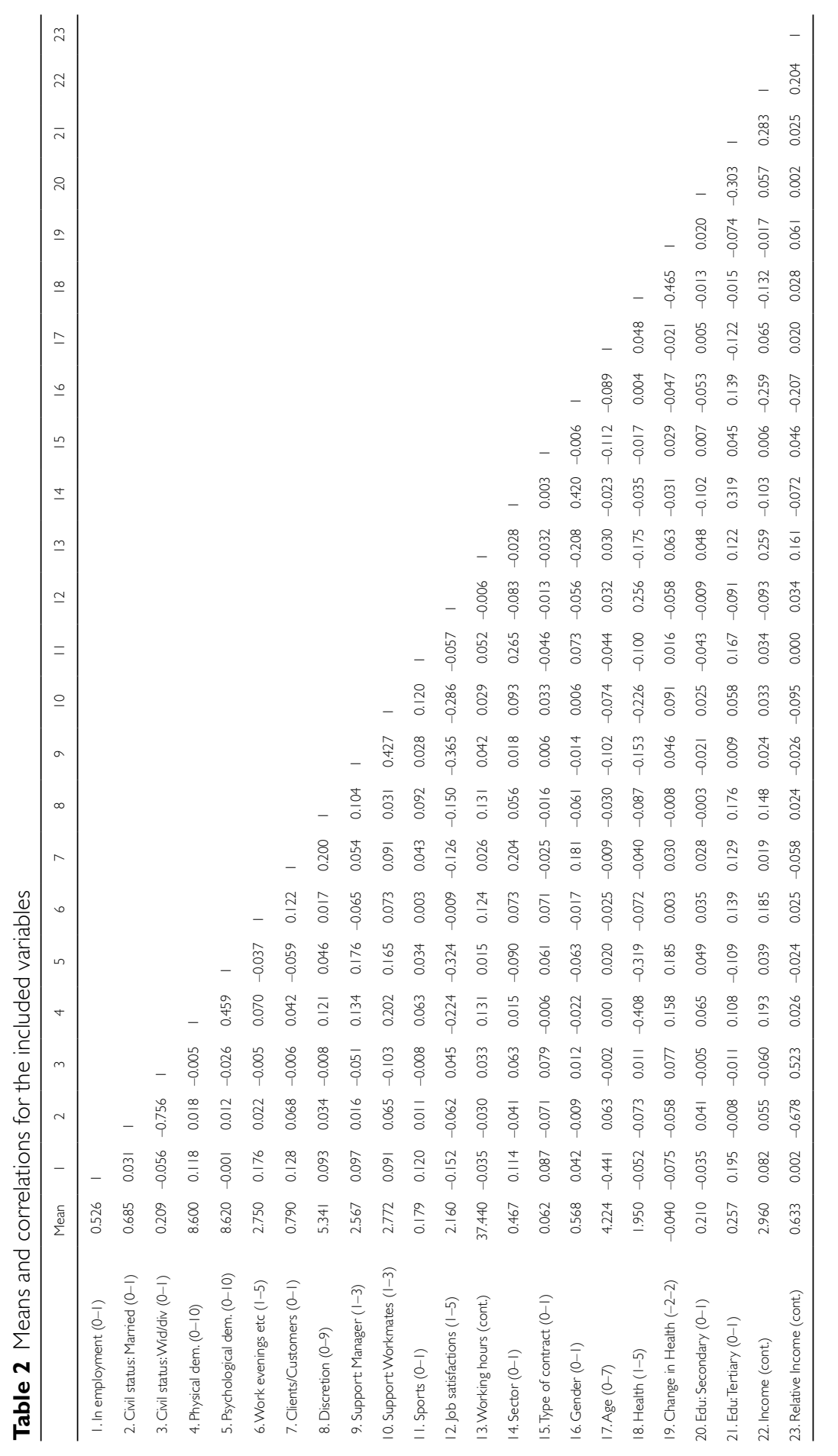


The distribution of the dependent variable is binomial and we use linear probability regressions to estimate the outcome. There are two reasons to choose an ordinary least square regression (OLS) instead of a logistic regression. First, the OLS allows straightforward interpretation of a binary outcome in terms of proportions. It has also been shown that a linear model basically provides estimates of significance that are equivalent to those of the logistic model (Hellevik, 2009). Second, the OLS produces estimates that are comparable across models, which is not the case for the logistic model (Mood, 2010; Winship \& Mare, 1984). However, robust standard errors are used in order to correct for possible heteroskedasticity. The regression will be presented in several models. First, we present simple bivariate regressions between the dependent variable and all the independents. Thereafter, we continue with four different models. In Model 1, only variables on immediate working conditions are included. Model 2 adds the job satisfaction variable, which is theoretically believed to mediate some of the effect of the working conditions variables, that is, poor working conditions decrease job satisfaction. Model 3 includes controls for type of job (such as sector), and Model 4 includes the rest of the controls (such as age and income).

We also conducted an extensive analysis of possible interaction effects between age and the work-related variables in Model 1 (including job satisfaction). The purpose is to test whether any of the demand variables increase the effect of aging on leaving and, vice versa, whether any of the resource variables decrease this effect. However, as discussed above, there is also a possibility that aging decreases any effect of either demands or resources, which can be interpreted as a normative effect of aging. Each of the interactions has been tested separately, but with control for the full model (Model 4). However, only three interactions were statistically significant and therefore presented.

\section{Results}

Table 3 presents the results of the regression on remaining in employment. The bivariate analysis in column 1 shows that most of the work-related variables are related to the chance of remaining employed in the expected direction. However, the direction of two of the demand variables is opposite to that expected: working evenings or weekends and having a direct contact with clients both seem to be positively related to staying.

In Model 1, the working conditions variables are subjected to a multivariate analysis. One job demand of significance is physical demands: having good work capacity in relation to physical job demands implies a higher probability of still being in employment 8 years later. As indicated in the bivariate analysis, neither working evenings or weekends nor having a direct contact with clients can be interpreted as a job demand. One possible explanation for the former finding is that it is an effect of selection; it may be that devoted workers are captured by this instrument, which should instead be regarded as indicating some kind of work commitment. Concerning the latter finding on working with clients, we are inclined to regard this as an aspect of job resources. Social interactions with clients, patients, and customers seem to help retain workers at their job. Exactly what this relationship looks like-that is, whether it is a matter of responsibility or that one enjoys the social interaction with clients-is not clear (Tourangeau et al., 2010). In Model 2, however, we can see that the coefficient is somewhat reduced when job satisfaction is controlled for, which provides some support for the second explanation.

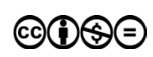


Table 3 Staying in employment. OLS Regression (Robust Standard Errors)

\begin{tabular}{|c|c|c|c|c|c|}
\hline & Bivariate & Model I & Model 2 & Model 3 & Model 4 \\
\hline $\begin{array}{l}\text { Work capacity relative to physical } \\
\text { demands (very bad } 0 \text { to very good } 10 \text { ) }\end{array}$ & $0.031 * *$ & $0.028 *$ & $0.026 *$ & $0.030 *$ & $0.029 *$ \\
\hline $\begin{array}{l}\text { Work capacity relative to } \\
\text { psychological demands } \\
\text { (very bad } 0 \text { to very good } 10 \text { ) }\end{array}$ & 0.000 & -0.018 & $-0.026+$ & $-0.028 *$ & -0.014 \\
\hline $\begin{array}{l}\text { Working evenings or weekends } \\
\text { (Never I to many times a week } 5 \text { ) }\end{array}$ & $0.063 * * * *$ & $0.057 * * * *$ & 0.057 **** & 0.057 **** & $0.048 * * * *$ \\
\hline $\begin{array}{l}\text { Direct contact with customers/ } \\
\text { clients (no/yes) }\end{array}$ & $0.157 * *$ & $0.100 *$ & $0.086+$ & 0.080 & $0.097+$ \\
\hline $\begin{array}{l}\text { Freedom to decide work facets } \\
\text { (scale) }\end{array}$ & $0.020 *$ & 0.010 & 0.008 & 0.010 & 0.003 \\
\hline Support from management (no/yes) & $0.076^{*}$ & $0.069 *$ & 0.046 & 0.051 & 0.018 \\
\hline Support from workmates (no/yes) & $0.100 *$ & 0.009 & 0.005 & -0.012 & -0.021 \\
\hline $\begin{array}{l}\text { Sports (practice) during working } \\
\text { hours (no/yes) }\end{array}$ & $0.156 * *$ & $0.135 *$ & $0.133^{*}$ & $0.129 *$ & $0.095 *$ \\
\hline $\begin{array}{l}\text { Feelings on the way to the job } \\
\text { (happy and satisfied - discomfort) }\end{array}$ & $-0.087 * * * *$ & & $-0.067 *$ & $-0.063 *$ & $-0.058 *$ \\
\hline Working hours & -0.002 & & & $-0.005^{*}$ & $-0.005^{*}$ \\
\hline Sector $($ private $=0 ;$ public $=1)$ & $0.114 * * *$ & & & 0.038 & 0.056 \\
\hline $\begin{array}{l}\text { Type of contract (open-ended }=0 \text {; } \\
\text { fixed term }=1 \text { ) }\end{array}$ & $0.180 *$ & & & $0.175 * *$ & 0.081 \\
\hline Gender $($ male $=0$; female $=1)$ & 0.042 & & & & -0.047 \\
\hline Age & $-0.10 \mid$ ****** & & & & $-0.098 * * * *$ \\
\hline \multicolumn{6}{|l|}{ Civil status (unmarried) } \\
\hline - Married & -0.028 & & & & 0.067 \\
\hline - Divorced/widow & -0.093 & & & & -0.049 \\
\hline $\begin{array}{l}\text { (ill)Health ( } 5 \text { points, from very } \\
\text { good-very bad) }\end{array}$ & -0.029 & & & & -0.002 \\
\hline Worsening health $(2010 / 11-2002 / 03)$ & $-0.063+$ & & & & $-0.078^{*}$ \\
\hline \multicolumn{6}{|l|}{ Education (Primary) } \\
\hline - Secondary & 0.032 & & & & -0.028 \\
\hline -Tertiary & $0.232 * * * *$ & & & & 0.053 \\
\hline Income & $0.027 *$ & & & & 0.009 \\
\hline $\begin{array}{l}\text { Proportion of total household } \\
\text { income }\end{array}$ & 0.004 & & & & 0.162 \\
\hline Intercept & & -0.072 & 0.274 & $0.406+$ & $0.723 * *$ \\
\hline R2 & & 0.077 & 0.087 & 0.103 & 0.296 \\
\hline $\mathrm{N}$ & 580 & & & & \\
\hline
\end{tabular}

Note: $+p<0.10$; $p<<0.05$; *** $<0.01$; **** $p<0.001$.

The defined job resources show mixed relevance in the multiple regression. Decision latitude is no longer significant, and neither is support from workmates. Support from management and sports during working hours is still statistically significant. The latter 
result implies that the possibility to exercise at the workplace increases the probability of still being employed 8 years later. There are at least three possible explanations for the relationship. First, there is a direct relationship of training, meaning that it makes the worker sufficiently fit to stay longer in employment. Second, the relationship is spurious and indicates workplaces that are satisfying in general. Third, it is an effect of selection-fit workers take advantage of the opportunity to train at the workplace.

In Model 2, job satisfaction is added to the regression and, on its own, has a clear relationship in the expected direction: the more satisfied a person is with his or her job, the higher their probability of staying. When this variable is added to the analysis, the variable of support from management becomes nonsignificant, and the variable about client contacts weakly significant $(\mathrm{p}<0.10)$. However, one other variable becomes weakly statistically significant $(\mathrm{p}<0.10)$ : if a person thinks that he or she cannot deal with the psychological demands of the job, this decreases the probability that he or she will be retired in 2010/2011. This is the opposite of what was expected when defining the variable as an indicator of job demands. Model 3 introduces variables concerning type of job. The main result is that most effects of Model 2 are unchanged, although the pattern regarding client contacts (nonsignificant) and psychological demands $(\mathrm{p}<0.05)$ becomes clearer.

Model 4 includes all variables. We can conclude that the central effects of the working conditions variables from Model 2 remain intact, with the exception of psychological demands and the variables measuring support. We see that even when health is added as a control, the impact of sports during working hours remains significant. This strengthens the hypothesis of a direct effect of exercise. Looking at the added controls, age is of major importance, together with the variable measuring changing health (measuring worsening health) between 2002/2003 and 2010/2011.

The age effect is of central importance to the analysis. From one theoretical strand, it is possible to interpret the effect as a consequence of diminishing capacities. However, job demands and job resources can interact with the age effect. Job demands could add to the age effect by successively making aging a more pressing matter. Job resources, on the other hand, could reduce the age effect by providing means for handling difficult working conditions. It is therefore of interest to determine whether there are job demands or job resources that reinforce or reduce the age effect. However, a competing hypothesis is that the age effect has nothing to do with diminishing capacities at all, but is an indication of the strong values and norms associated with retiring when a person is of retirement age. From this perspective, the significance of demands and resources should decline the older a person gets, that is, they should play a decreasing role in the decision to retire.

Control for all variables in model 4 in Table 3. OLS Regression (Robust Standard Errors). $\mathrm{N}=580$.

Table 4 summarizes the three interaction effects that we find between age and the working conditions variables. The first is related to physical demands. The results support the second of the two competing hypotheses above. It seems that age conditions the impact of physical demands by decreasing the effect of physical demands as a person gets older. This means that being physically fit for one's job becomes less and less of a reason to stay the closer the employee gets to age 67. Moreover, the other two interactions also move in the direction of the second hypothesis. The second interaction shows a reduced effect of support from workmates on remaining in work as the individual gets

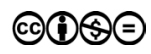


Table 4 Interactions for age and working conditions

\begin{tabular}{|c|c|c|c|}
\hline & MI & M2 & M3 \\
\hline Work capacity relative to physical demands & $0.068 * *$ & & \\
\hline Support from workmates & & $0.161+$ & \\
\hline Direct contact with customers/clients & & & $0.34 \mid * * *$ \\
\hline Age & -0.022 & 0.013 & $-0.052 *$ \\
\hline \multicolumn{4}{|l|}{ Age $\times$ (multiplied with) } \\
\hline Physical demands & $-0.009 *$ & & \\
\hline Support workmates & & $-0.040 *$ & \\
\hline Direct contact with clients/customers & & & $-0.057^{*}$ \\
\hline
\end{tabular}

Note: $+p<0.10$; ${ }^{*} p<0.05$; ** $p<0.01$; *** $p<0.001$.

older. In a similar vein, the effect of the third interaction-direct contacts with customer/ clients on staying-diminishes with age. Figure 1 shows the interaction effects with $95 \%$ confidence intervals (CIs).

\section{Conclusion}

In this paper, we have studied the effect of working conditions on the probability of staying employed after reaching the age of eligibility for old-age pension. Following the conceptualizations in the Job Demand-Resource model, our general hypothesis is that job demands push employees out of employment and that various job resources can counteract this process, either by motivating the individual to keep working or by buffering the effects of job demands. Furthermore, aging itself may entail the experience of increased job demands, owing to the natural process of diminishing physical resources.

The analyses of these questions have been based on panel data from the Swedish Living Conditions Survey (ULF). We have studied the way in which a person's work situation from 8 years earlier (in our case, 2002/2003) can predict the outcomes of remaining in work. However, this rather long time frame must be emphasized; our study shows the long-term effects of working conditions. One obvious weakness of our data is that we cannot control for changes in respondents' working conditions and life situation between these two points in time.

Concerning work-related variables, the most reliable results are that physical working conditions and job satisfaction 8 years earlier are the best predictors of the outcome. Feeling fit to handle physical job demands when a person is in his or her fifties seems to be vital for being able to continue working. Being satisfied with the job during this period is also important. From a policy perspective, it would seem to be important to provide working conditions that keep employees in their fifties satisfied with their job and support them in taking care of their physical fitness. This can prolong their working life. Perhaps the results of training during working hours can be interpreted in this light.

However, the study also reveals a very strong effect of aging on the likelihood of retiring. From the age of 60 to the age of 67 , the percentage of people still working 
Figure I: Marginal effects of physical demands, support from workmates, and direct contacts with clients and customers, conditional on age with 95\% confidence intervals (Cls).
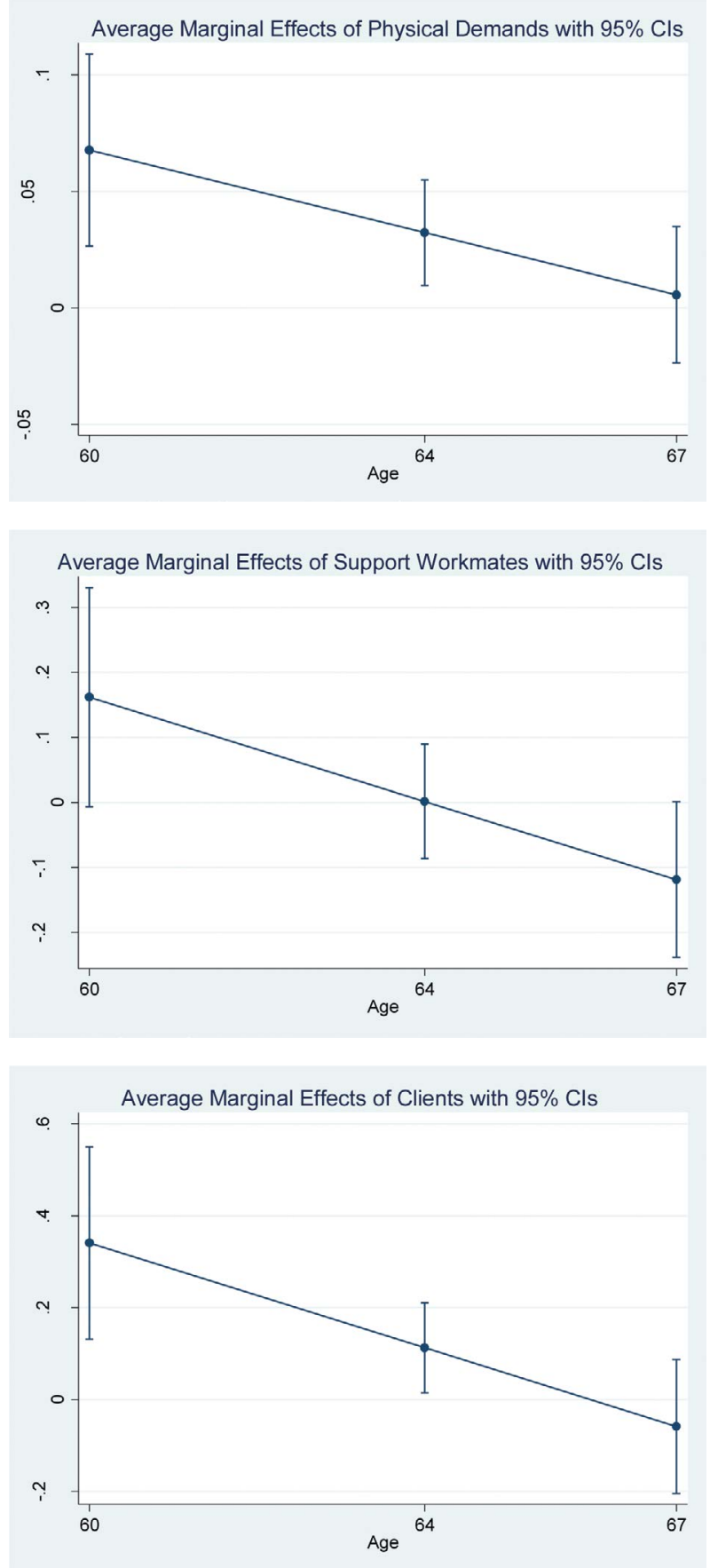
decreases linearly from $88 \%$ to $28 \%$. How should this effect be interpreted? Is it really an effect of deteriorating physical and mental energy related to aging, as some research has claimed (Radl, 2013; Thijssen \& Rocco, 2010)? Or are norms and values at play that cause employees to prefer receiving the pension the older they get? We strongly suspect that the latter process is the explanation. Indications pointing in this direction come from the interaction showing that physical job demands and job resources have a smaller impact as a person gets older. This means that people quit working when they get older, regardless of how fit they are and of what job resources are available. The norm to quit, which is emphasized by the institutionalized pension system, and the values and preferences connected to life as a pensioner, are strong social forces that condition workers' retirement decisions.

Our findings can help us understand how powerful economic incentives are in relation to other factors. Recent changes in the pension system make Sweden an interesting case. In the new pension system, incentives were introduced to keep the workforce in employment longer. However, our study indicates that other factors, such as values and norms, may counteract such incentives (Albin et al., 2015). In short, the goal of keeping the workforce in employment longer cannot be achieved through economic reforms alone. Nor can it be achieved by improving older workers' abilities to meet work demands or by improving working conditions only. A shift in norms and values seems to also be necessary.

\section{References}

Adams GA and Rau BL. (2011) Putting off tomorrow to do what you want today: planning for retirement. American Psychologist 66: 180. doi: http://dx.doi.org/10.1037/a0022131

Albin M, Bodin T and Wadensjö E. (2015) National Report Sweden. In: Hasselhorn HM (ed) Understanding employment participation of older workers: Creating a knowledge base for future labour market challenges. Berlin: Federal Ministry of Labour and Social Affairs (BMAS) and Federal Institute for Occupational Safety and Health (BAuA). BMAS/ BAuA.

Atchley RC. (1982) Retirement as a Social Institution. Annual Review of Sociology 8: 263-287. doi: http://www.jstor.org/stable/2945996

Bakker AB and Demerouti E. (2007) The job demands-resources model: State of the art. Journal of managerial psychology 22: 309-328. doi: http://dx.doi.org/10.1108/026839407 10733115

Borg TLV. (1999) Work environment and self-rated health as predictors of remaining in work 5 years later among Danish employees 35-59 years of age. Experimental Aging Research 25: 429-434. doi: http://dx.doi.org/10.1080/036107399243904

Clark A. (2005) What makes a good job? Evidence from OECD countries. Job Quality and Employer Behaviour. Springer, 11-30. doi: http://dx.doi.org/10.1057/97802303786432

Demerouti E and Bakker AB. (2011) The job demands-resources model: Challenges for future research. SA Journal of Industrial Psychology 37: 01-09. doi: http://ref.scielo.org/t9rpvj

Ekerdt DJ. (2010) Frontiers of Research on Work and Retirement. Journals of Gerontology Series B-Psychological Sciences and Social Sciences 65: 69-80. doi: http://dx.doi. org/10.1093/geronb/gbp109

Elovainio M, Forma P, Kivimäki M, Sinervo T, Sutinen R and Laine M. (2005) Job demands and job control as correlates of early retirement thoughts in Finnish social and health care employees. Work \& Stress 19: 84-92. doi: http://dx.doi.org/10.1080/02678370500084623 
Elovainio M, Kivimäki M, Vahtera J, Ojanlatva A, Korkeila K, Suominen S, Helenius H and Koskenvuo M (2003) Social support, early retirement, and a retirement preference: a study of 10,489 Finnish adults. Journal of Occupational and Environmental Medicine 45: 433-439. doi: http://dx.doi.org/10.1097/01.jom.0000058334.05741.7a

Euwals R, van Vuuren D and Wolthoff R. (2010) Early retirement behaviour in the Netherlands: Evidence from a policy reform. De Economist 158: 209-236. doi: http://dx.doi. org/10.1007/s10645-010-9139-0

Evers G and Ester P. (2013) The Ageing workforce, human capital and the Bermuda triangle: an interdependent analysis. In: Taylor P (ed) Older workers in an ageing society: critical topics in research and policy Cheltenham: Edward Elgar. doi: http://dx.doi.org/10.4337/ 9781782540106.00014

Gobeski KT and Beehr TA. (2009) How retirees work: predictors of different types of bridge employment. Journal of Organizational Behavior 30: 401-425. doi: http://dx.doi. org/10.1002/job.547

Hamblin KA. (2010) Changes to policies for work and retirement in EU15 nations (19952005): An exploration of policy packages for the 50-plus cohort. International Journal of Ageing and Later Life 5: 13-43.

Hansson RO, DeKoekkoek PD, Neece WM and Patterson DW. (1997) Successful aging at work: Annual review, 1992-1996: The older worker and transitions to retirement. Journal of Vocational Behavior 51: 202-233. doi: http://dx.doi.org/10.1006/jvbe.1997.1605

Hayward MD, Grady WR, Hardy MA and Sommers D. (1989) Occupational influences on retirement, disability, and death. Demography 26: 393-409. doi: http://dx.doi. org $/ 10.2307 / 2061600$

Hellevik O. (2009) Linear versus logistic regression when the dependent variable is a dichotomy. Quality \& Quantity 43: 59-74. doi: http://dx.doi.org/10.1007/s11135-007-9077-3

Henkens K. (1999) Retirement intentions and spousal support: A multi-actor approach. The Journals of Gerontology Series B: Psychological Sciences and Social Sciences 54: S63-S73. doi: http://dx.doi.org/10.1093/geronb/54B.2.S63

Henkens K and Tazelaar F. (1997) Explaining retirement decisions of civil servants in the Netherlands. Intentions, behavior; and the discrepancy between the two. Research on Aging 19: 139-173. doi: http://dx.doi.org/10.1177/0164027597192001

Henkens K and Van Solinge H. (2002) Spousal influences on the decision to retire. International Journal of Sociology: 55-74. doi: http://www.jstor.org/stable/20628649

Hom PW and Kinicki AJ. (2001) Toward a greater understanding of how dissatisfaction drives employee turnover. Academy of Management Journal 44: 975-987. doi: http:// dx.doi.org/10.2307/3069441

Karasek R and Theorell T. (1990) Healthy work: stress, productivity, and the reconstruction of working life, New York: Basic Books.

Krause N, Lynch J, Kaplan GA, Cohen RD, Goldberg DE and Salonen JT. (1997) Predictors of disability retirement. Scandinavian Journal of Work and Environmental Health 23: 403-413. doi: http://dx.doi.org/10.5271/sjweh.262

Kubicek B, Korunka C, Hoonakker P and Raymo JM. (2010) Work and family characteristics as predictors of early retirement in married men and women. Research on Aging 32: 467-498. doi: http://dx.doi.org/10.1177/0164027510364120

Lin T-C. (2001) Letter to the Editor: Impact of Job Stress on Early Retirement Intention. International Journal of Stress Management 8: 243-247. doi: http://dx.doi.org/10.1023/ A:1011395227349

Lund T, Iversen L and Poulsen KB. (2001) Work environment factors, health, lifestyle and marital status as predictors of job change and early retirement in physically heavy occupations. American Journal of Industrial Medicine 40: 161-169. doi: http://dx.doi. org/10.1002/ajim.1084 
Lund T and Villadsen E. (2005) Who retires early and why? Determinants of early retirement pension among Danish employees 57-62 years. European Journal of Ageing 2: 275-280. doi: http://dx.doi.org/10.1007/s10433-005-0013-x

Maslach C and Jackson SE. (1981) The measurement of experienced burnout. Journal of Organizational Behavior 2: 99-113. doi: http://dx.doi.org/0.1002/job.4030020205

Mein G, Martikainen P, Stansfeld SA, Brunner EJ, Fuhrer R and Marmot MG. (2000) Predictors of early retirement in British civil servants. Age and Ageing 29: 529-536. doi: http:// dx.doi.org/10.1093/ageing/29.6.529

Mood C. (2010) Logistic Regression: Why We Cannot Do What We Think We Can Do, and What We Can Do About It. European Sociological Review 26: 67-82. doi: http://dx.doi. org/10.1093/esr/jcp006

Morrison MH. (1986) Work and Retirement in an Aging Society. Daedalus 115: 269-293. doi: http://www.jstor.org/stable/20025034

Mutchler JE, Burr JA, Pienta AM and Massagli MP. (1997) Pathways to labor force exit: Work transitions and work instability. The Journals of Gerontology Series B: Psychological Sciences and Social Sciences 52: S4-S12. doi: http://dx.doi.org/10.1093/geronb/52B.1.S4

Nilsson K. (2016) Conceptualisation of ageing in relation to factors of importance for extending working life-a review. Scandinavian Journal of Public Health 44: 490-505.

OECD. (2006) Ageing and employment policies. Live longer, work longer [a synthesis report]. Paris: Organisation for Economic Co-operation and Development (OECD).

Örestig J, Strandh M and Stattin M. (2013) A wish come true? A longitudinal analysis of the relationship between retirement preferences and the timing of retirement. Journal of Population Ageing 6: 99-118. doi: http://dx.doi.org/10.1007/s12062-012-9075-7

Pensionsmyndigheten (Swedish Pensions Agency). (2014) Medelpensioneringsålder och utträdesålder (The average age of retirement and exit ages) 2013.

Quinn JF, Burkhauser RV and Myers DA. (1990) Passing the torch: The influence of economic incentives on work and retirement. WE Upjohn Institute for Employment Research.

Radl J. (2013) Retirement Timing and Social Stratification. A Comparative Study of Labor Market Exit and Age Norms in Western Europe. De Gruyter. doi: http://hdl.handle. net/1814/14714

Rayson M. (2000) Fitness for work: the need for conducting a job analysis. Occupational Medicine 50: 434-436. doi: http://dx.doi.org/10.1093/occmed/50.6.434

Reitzes DC, Mutran EJ and Fernandez ME. (1998) The decision to retire: A career perspective. Social Science Quarterly. doi: http://www.jstor.org/stable/42863823.

Schalk R, Van Veldhoven M, De Lange AH, De Witte H, Kraus K, Stamov-Roßnagel C, Tordera, N, Van der Heijden B, Zappala S and Bal M. (2010) Moving European research on work and ageing forward: Overview and agenda. European Journal of Work and Organizational Psychology 19: 76-101. doi: http://dx.doi.org/10.1080/13594320802674629

Schreurs B, Van Emmerik H, De Cuyper N, Notelaers G and De Witte H. (2010) Job demands-resources and early retirement intention: Differences between blue-and white-collar workers. Economic and Industrial Democracy. doi: http://dx.doi. org/10.1177/0143831X10365931

Shultz KS and Wang M. (2007) The influence of specific physical health conditions on retirement decisions. The International Journal of Aging and Human Development 65: 149-161. doi: http://dx.doi.org/10.2190/AG.65.2.c

Siegrist J. (2008) Effort-reward imbalance and health in a globalized economy. Scandinavian Journal of Work Environment \& Health: 163-168.

Spector PE. (1997) Job Satisfaction: Application. Assessment, Causes, and Consequences. Sage Publications.

Svallfors S. (2007) Introduction. In: Svallfors S (ed) The Political Sociology of the Welfare State. Stanford: Stanford University Press. 
Szinovacz ME and Davey A. (2005) Predictors of perceptions of involuntary retirement. The Gerontologist 45: 36-47. doi: http://dx.doi.org/10.1093/geront/45.1.36

Szinovacz ME and DeViney S. (2000) Marital characteristics and retirement decisions. Research on Aging 22: 470-498. doi: http://dx.doi.org/10.1177/0164027500225002

Szinovacz ME, DeViney S and Davey A. (2001) Influences of family obligations and relationships on retirement variations by gender, race, and marital status. The Journals of Gerontology Series B: Psychological Sciences and Social Sciences 56: S20-S27. doi: http:// dx.doi.org/10.1093/geronb/56.1.S20

Szubert Z and Sobala W. (2005) Current determinants of early retirement among blue collar workers in Poland. International Journal of Occupational Medicine and Environmental Health 18: 177-184.

Tett RP and Meyer JP. (1993) Job satisfaction, organizational commitment, turnover intention, and turnover: path analyses based on meta-analytic findings. Personnel Psychology 46: 259-293. doi: http://dx.doi.org/10.1111/j.1744-6570.1993.tb00874.x

Thijssen J and Rocco T. (2010) Development of older workers: revisiting policies. Working and ageing: emerging theories and empirical perspectives. Luxembourg: Publications Office of the European Union.

Tourangeau AE, Cummings G, Cranley LA, Ferron EM and Harvey, S. (2010) Determinants of hospital nurse intention to remain employed: broadening our understanding. Journal of Advanced Nursing 66: 22-32. doi: http://dx.doi.org/10.1111/j.1365-2648.2009.05190.x

Tuomi K, Huuhtanen P, Nykyri E and Ilmarinen J. (2001) Promotion of work ability, the quality of work and retirement. Occupational Medicine 51: 318-324. doi: http://dx.doi. org/10.1093/occmed/51.5.318

van den Berg T, Elders L, de Zwart B and Burdorf A. (2008) The effects of work-related and individual factors on the Work Ability Index: a systematic review. Occupational and Environmental Medicine. doi: http://dx.doi.org/10.1093/occmed/51.5.318

Van der Doef M and Maes S. (1999) The job demand-control (-support) model and psychological well-being: a review of 20 years of empirical research. Work \& Stress 13: 87-114. doi: http://dx.doi.org/10.1080/026783799296084

van der Heijden B, Schalk R, van Veldhoven M, Desmette D and Gaillard, M. (2008) When a "worker" becomes an "older worker" The effects of age-related social identity on attitudes towards retirement and work. Career Development International 13: 168-185. doi: http://dx.doi.org/10.1108/13620430810860567

Von Bonsdorff ME, Shultz KS, Leskinen E and Tansky, J. (2009) The choice between retirement and bridge employment: A continuity theory and life course perspective. The International Journal of Aging and Human Development 69: 79-100. doi: http://dx.doi. org/10.2190/AG.69.2.a

Wang M. (2007) Profiling retirees in the retirement transition and adjustment process: examining the longitudinal change patterns of retirees' psychological well-being. Journal of Applied Psychology 92: 455. doi: http://dx.doi.org/10.1037/0021-9010.92.2.455

Wang M and Shultz KS. (2010) Employee retirement: A review and recommendations for future investigation. Journal of Management 36: 172-206. doi: http://dx.doi.org/ $10.1177 / 0149206309347957$

Winship C and Mare RD. (1984) Regression Models with Ordinal Variables. American Sociological Review 49: 512-525. doi: http://www.jstor.org/stable/2095465 